\title{
BDS Curriculum: Neglected Sibling
}

\author{
Khadija Iqbal $^{1}$ \\ MBBS, FCPS \\ Samra Asif ${ }^{2}$ \\ Third year BDS \\ Ibad-ur-Rehman ${ }^{3}$ \\ First year MBBS
}

\begin{abstract}
:
The medical educationists are emphasizing on the implementation of skills based curriculum which covers the oral health in a broader and global scale. Keeping in mind these things this study was conducted to know opinion of medical students regarding modern educational reforms and the present curriculum taught in their medical colleges.

Methodology: This survey was done in medical colleges with four year program in dentistry in Rawalpindi and Islamabad. A four-question survey about the format and characteristics of the dental curriculum was circulated among the 200 dental graduates graduating in the year 2014 belonging to different dental colleges in Rawalpindi and Islamabad. The respondents expressed their answers in yes or no. Respondents indicated the name of their school and answered survey questions. Descriptive statistics including percentage distribution for each response were used. Responses were recorded separately for all the four years.

Results: In response to the question about integration between oral diseases with systemic disease, almost all agreed that their curriculum is disjointed in first and second year. $40 \%$ of the students told that some integration is created in third and $30 \%$ agreed that the integration is there in fourth year. $20 \%$ said that the basic sciences were taught with clinical context in first and second year and was not done in third and fourth year. Exposure of dental students to community and public health services was around $20 \%$ in third year and $30 \%$ in fourth year. PBL and case based discussions are not used in the dental colleges in all years.

Conclusions: The dental curriculum in Pakistan needs to cover a much broader spectrum of diseases as well as patients. Linking the curriculum with modern tools like PBL can improve dental education. The link between the basic and clinical teaching and incorporation of community health can lead to marked shift in educational approach of the medical students.
\end{abstract}

KEYWORDS: M.B.B.S, dentistry, undergraduate, curriculum.

HOW TO CITE: Iqbal K, Asif S, Rehman IU. BDS Curriculum: Neglected Sibling. J Pak Dent Assoc 2017; 26(2): 79-82.

Received: 8 February 2017, Accepted: 5 May 2017

\section{INTRODUCTION}

$\mathrm{A}$ lot of debate is going on worldwide about the competency of medical graduates ${ }^{1}$. The M.B.B.S curriculum is undergoing reforms in this context to improve the quality of medical education and more focus is now on the skill component ${ }^{2}$. Whether we are successful or not but attempts are going on for improvements and innovations ${ }^{3}$. Dentistry is a linked field with medicine which deals with a large number of patients and dental disease also form a major factors troubling the lives of patients. In our country this field is almost totally

1. Professor Anatomy, Al Nafees Medical College, Isra University

2. Margalla Institute of health sciences, UHS, Lahore

3. Shifa College of Medicine, Shifa Tameere Millat University

Corresponding author: "Dr. Khadija Iqbal”

<Khadijaiqbal1972@gmail.com> neglected when the curricular reforms are taking place ${ }^{4}$. In western world the field of dentistry is growing like a modern industry but in our country it is treated like a second class degree $^{5}$. The current curriculum debate in Pakistan is mostly revolving around arguments on shuffling various topics from one subject to another. It totally ignores the importance of our social demographics ${ }^{6}$. We do teach Implants to our under-graduates, but we forget that Implants is only minor percentage of the market needs. The designing of curriculum needs to know the patients for which the curriculum is designed. In our country the dental patients are the two extremes the paediatric and geriatric but the curriculum never focuses these two age groups ${ }^{7}$. In Pakistan, there is no dearth of experienced professionals and academicians, who have the global exposure to upgrade our curriculum and enable faster access to global developments ${ }^{8}$. In India the Paediatric and preventive dentistry is taught in clinical years which makes the students aware about the prevalence and treatment of paediatric dentistry ${ }^{9}$. The patients of dentistry 
are increasing day by day and they need specialist doctors to fulfil their needs. Many researchers have proposed a model for dental education that can built critical thinking in dental graduates and also create professionalism as well ${ }^{10}$. Oral health is a critical component of human health needs evidence-based approach to clinical decision making which built on integrative understanding of basic and applied science $^{11}$. In Harward School of dentistry integrated clinical practice of dental care for adults occurs in the in clinical and preclinical years ${ }^{12}$. Research skills are developed with opportunities to become involved in faculty research projects as well as in the conduct of community health projects. PBL in the final year, provides an opportunity to experience and learn from different clinical contexts ${ }^{13}$. In many countries a six year BDS programme has been introduced ${ }^{14}$. After the publication of the Flexner report, Gies worked to trigger significant change in dental education at the time. He emphasized the importance of stronger scholarship in biomedical and clinical sciences but many of Gies's recommendations did not gain popularity ${ }^{15}$. The American Dental Education Association (ADEA) developed programs and initiatives to support the reform of dental education ${ }^{16}$.

The present curriculum of B.D.S approved by the P.M.D.C is not according to the modern concepts of dentistry. Pakistan needs a paradigm shift towards research oriented and clinical based scientific methodologies with emphasized training on medical jurisprudence and human consumer rights as well ${ }^{17}$. Case based teaching and PBL incorporation can lead to improvement in competencies of medical graduates ${ }^{18}$. The oral health is a spectrum of diseases that needs a thinking mind to cure the disease ${ }^{19}$. The designing of the curriculum should be based on skills but to covers the oral health in a broader and global scale. Keeping in mind these things this study was conducted to know opinion of medical students regarding modern educational reforms and the present curriculum taught in their medical colleges.

\section{SUBJECTS AND METHOD}

This survey was done in medical colleges with four year programme in dentistry in Rawalpindi and Islamabad. A four-question survey about the format and characteristics of the dental curriculum was circulated among the 200 dental graduates graduating in the year 2014 belonging to different dental colleges in Rawalpindi and Islamabad. The respondents expressed their answers in yes or no. Respondents indicated the name of their school and answered survey questions. Descriptive statistics including percentage distribution for each response were used. Responses were recorded separately for all the four years.

\section{RESULTS}

In response to the question about integration between oral diseases with systemic disease, almost all agreed that their curriculum is disjointed in first and second year. $40 \%$ of the students told that some integration is done in third and $30 \%$ agreed that the integration is there in fourth year. $20 \%$ said that the basic sciences were taught in clinical context. Contextual learning was done in first and second year and was not done in third and fourth year. Exposure of dental students to community and public health services was around $20 \%$ in third year and 30\% in fourth year. PBL and case based discussions are not used in the dental colleges in all years (Table $\mathbf{1}$ ).

Table 1. Table Showing the Response of Students Regarding Different Factors Showing Integration of Dental with Systemic Health

\begin{tabular}{|c|c|c|c|c|}
\hline Factors & First year & Second year & Third year & Fourth year \\
\hline $\begin{array}{l}\text { integration between oral disease with } \\
\text { systemic disease is done }\end{array}$ & $100 \%$ disagree & $100 \%$ disagree & $40 \%$ agreed & $30 \%$ agreed \\
\hline $\begin{array}{l}\text { Contextual learning between basic and } \\
\text { clinical sciences is done }\end{array}$ & 20\% Agreed & $20 \%$ agreed & $100 \%$ disagreed & $100 \%$ disagreed \\
\hline $\begin{array}{l}\text { Exposure of dental students to community } \\
\text { and public health services is done }\end{array}$ & $100 \%$ disagreed & $100 \%$ disagreed & $20 \%$ agreed & $30 \%$ agreed \\
\hline $\begin{array}{c}\text { Exposure to old and paediatric patients is } \\
\text { done }\end{array}$ & $100 \%$ disagreed & $20 \%$ agreed & $40 \%$ agreed & $40 \%$ agreed \\
\hline $\begin{array}{l}\text { PBL and case based discussions are part of } \\
\text { curriculum }\end{array}$ & $100 \%$ disagreed & $100 \%$ disagreed & $100 \%$ disagreed & $100 \%$ disagreed \\
\hline
\end{tabular}




\section{DISCUSSION}

Field of dentistry is not only linked to the oral cavity but it is a whole spectrum which needs to be revealed. The dentist is not the man needed to extract the toot or treat the tooth ache but he should be trained to diagnose the associated disease with oral pathology. $40 \%$ of the students told that some integration is done in third and 30\% agreed that it is there in the fourth year. The content taught in a disintegrated manner does not help the student in contextual learning. Development of a good curriculum reflects objectivity so as to ensure learning to an extent which can make students critical thinkers and also identify their learning needs ${ }^{21}$. The dental curriculum in Pakistan has not yet achieved this level and we have not addressed basic problems of dental patients. The stress on oral hygiene through media campaigns has created awareness in patients and reduction in caries is expected but cases still exist in the adult population ${ }^{22}$. This means that although the awareness is there the diagnosis and care required to treat and correlate with major systemic diseases is still lacking. Oral diseases are not a localized infection but these show link with systemic like diabetes mellitus and cardiovascular diseases. The link is so great that the fetal heart disease might be seen along with tooth abnormalities. Tooth discoloration may be related to drug interactions ${ }^{23}$. Morbidity and mortality from oral and pharyngeal cancer is significantly high so the need exists to explore the complications of these diseases in context with the oral pathology ${ }^{24}$. Epidemiologists have shown that until we have standardized, comprehensive programs to screen for oral cancer, patients will continue to get diagnosed far too late when the metastasis has taken place. Association of human papilloma virus with oral cancer dental hygiene oral cancer exams must be performed by the dental hygienists ${ }^{25}$.

The dental curriculum is overloaded with marginally important content which should be replaced with essential clinical knowledge. In addition, the curriculum is poorly integrated. The clinical problems are not used to teach the content making it difficult for the students to apply the knowledge of basic sciences on the patient ${ }^{19}$. The disjointed and overcrowded content does not create the research environment required to improve the patient care. $40 \%$ of the students in third and 30\% in fourth year agreed that integration between basic and clinical sciences is done (Table 1).

Community dentistry needs to be revived in our country. The increasing use of tobacco and smoking is a major threat for oral cancers ${ }^{26}$. Awareness has to create regarding dental hygiene so as to reduce the risk of these diseases. In a study done selected oral epithelial lesions were evaluated by oral brush biopsy with a computer-assisted method of analysis and results showed this tool can help identify precancers and potentially curable cancers ${ }^{27}$. Exposure of dental students to community and public health services was around $20 \%$ in third year and $30 \%$ in fourth year. Population-based surveys indicate that cancer screening and tobacco cessation advice are underutilized in the dental practice.

All over the world many medical school utilize PBL for dental education like Harvard, Connecticut, and the University of British Columbia ${ }^{28}$. In Pakistan PBL and case based discussions are not used in the dental colleges as a priority $^{29}$. Many recommendations have been made which suggest that the training of a dental practitioner for the twenty first century will require substantial integration of basic medical knowledge with the clinical aspects. This can be done with the incorporation of $\mathrm{PBL}^{30}$. It is felt that dentally related biomedical cases suitable for a PBL program have not been developed and this educational approach has not been utilized in Pakistan as yet.

\section{CONCLUSION}

The dental curriculum in Pakistan needs to cover a much broader spectrum of diseases as well as patients. Linking the curriculum with modern tools like PBL can improve dental education. The link between the basic and clinical teaching and incorporation of community health can lead to marked shift in educational approach of the medical students.

\section{REFERENCES}

1. McHarg J, Kay EJ. The anatomy of a new dental curriculum. Br Dent J 2008; 204: 635-8.

2. Hazmi MA, Tekian AS, el-Mahdy S, Lambourne A. Performance of men and woman students at King Saud University, Riyadh: 10-year retrospective study. Med Educ 1967; 21: 358-61.

3. Patel J, Fox K, Grieveson B, Youngson CC. Undergraduate training as preparation for vocational training in England: a survey of vocational dental practitioners' and their trainers 'views. Br Dent J 2006; 9-15.

4. Ryding HA, Murphy HJ. Assessing outcomes of curricular change: a view from program graduates. J Dent Educ 2001; 65: 422-6.

5. Gerrow JD, Murphy HJ, Boyd MA. Competencies for the beginning dental practitioner in Canada: a validity survey. J Dent Educ 2006; 70: 1076-80.

6. Department of Health. Oral health survey 2001. HongKong: Dental Service Head Office, Department of Health 2002: 37-60. 
7. Ventä I, Lindqvist C, Ylipaavalniemi P. Malpractice claims for permanent nerve injuries related to third molar removals. Acta Odontol Scand 1998; 56: 193-6.

8. Wiseman $\mathrm{M}$. The role of the dentist in recognizing elder abuse. J Can Dent Assoc 2008; 74: 715-20.

9. Hendricson WD. Changes in educational methodologies in predoctoral dental education: finding the perfect intersection. J Dent Educ 2012; 76: 118-41.

10. Nadershahi NA. Assessment of case-based integrated learning as part of dental curriculum reform. Ed.D. dissertation, University of the Pacific, 2011. Google Scholar

11. Haden NK, Beemsterboer PL, Weaver RG, Valachovic RW. An update on future dental school faculty. J Dent Educ 2000; 64: 657-73.

12. Featherstone JDB. The science and practice of caries prevention. J Amer Dent Assoc 2000; 131: 887-99.

13. Wolsky SL, McNamara JA. Orthodontic services provided by general dentists. Amer J Ortho Dentofac Orthpaed 1996; 110: 211-6.

14. Sanders AE, Lushington K. Sources of stress for Australian dental students. J Dent Educ 1999; 63: 68897. Question of the Month. J Amer Dent Assoc 1996; 27: 1300 .

15. Clareboets, V. Sivarajasingam, I. G. Smoking cessation advice: knowledge, attitude and practice among clinical dental studentsBDJ; 2010: 4-10

16. M. McGurk, S. E. Scott.The reality of identifying early oral cancer in the general dental practice, BDJ, 2010; 8: 347-349

17. Schilling K, Ginn DS, Mickelson P, et al. Integration of information-seeking skills and activities into a problembased curriculum. Bull Med Lib Assoc 1995; 83: 176-83.

18. Regehr G, Martin J, Hutchinson C, et al. The effect of tutors' content expertise on student learning, group process and participant satisfaction in a problem-based learning curriculum. Teach Learn Med 1995; 7: 225-32
19. Koh G C-H, Khoo HE, Wong ML, Koh D. The effects of problem-based learning during medical school on physician competency: a systematic review. CMAJ 2008; 178: 34-41.

20. Winning T, Townsend G. Problem-based learning in dental education: what's the evidence for and against and is it worth the effort? Aust Dent J 2007; 52: 2-9.

21. Pyle MA, Goldberg JS. Engineering curriculum change at a private midwest school of dental medicine: a faculty innovation. J Dent Educ 2008; 72: 288-98.

22. Iacopino AM. The influence of "new science" on dental education: current concepts, trends, and models for the future. J Dent Educ 2007; 71: 450-62.

23. Ryder MI, Sargent P, Perry D. Evolution and revolution: the curriculum reform process at UCSF. J Dent Educ 2008; 72: 1516-30.

24. Edelstein BL. Evidence-based dental care for children and the age 1 dental visit. Pediatric Annals 1998; 27: $569-74$.

25. Offenbacher S, Beck JD. Periodontitis: a potential risk factor for spontaneous preterm birth. Compend Cont Educ Dent 1998; 19: 40-5.

26. McDerra EJC, Pollard MA, Curzon MEJ. The dental status of asthmatic British school children. Pediatr Dent 1998; 20: 281-7

27. Morse Z, Nakahara S. English language education in Japanese dental schools. Eur J Dent Educ 2001; 5: 168172.

28. 9. Rodis OMM, Matsumura S, Kariya N. Undergraduate dental English education in Japanese dental schools. J Dent Educ 2013; 77: 656-663.

29. Barrows HS. The essentials of problem-based learning. J Dent Educ 1998; 62: 630-3.

30. Hartling L, Spooner C, Tjosvold L, Oswald A. Problembased learning in preclinical medical education: 22 years of outcome research. Med Teach 2010; 32: 28-35. 